\title{
STATUS AND DIVERSITY OF BIRDS OF RAMNA PARK, DHAKA, BANGLADESH
}

\author{
Sultana Rajia*, Md. Mahabub Alam, Gawsia Wahidunnessa Chowdhury, \\ Muntasir Akash and Md. Anwarul Islam \\ Department of Zoology, Faculty of Biological Sciences \\ University of Dhaka, Dhaka-1000, Bangladesh
}

\begin{abstract}
A study on status and diversity of birds of Ramna Park, Dhaka, Bangladesh was conducted from July 2013 to March 2014. Data were collected through direct field observations where 6 days had been spent in every month in the field. A total of 50 species of birds belonging to 11 orders and 28 families were observed. Of the 50 species, $84 \%$ were residents and $16 \%$ migrants, $50 \%$ were passerines, $50 \%$ non-passerines. Passeriformes presented the highest number $(25$ species $)$ of observed birds. Only Clamator jacobinus was recorded as summer migrant among the migratory birds. We found Psittacula eupatria considered as Near Threatened globally according to IUCN. Corvus splendens was the most common with the highest number of individuals in comparison to other bird species. We observed single individual of Clamator jacobinus followed by Psittacula eupatria and Apus pacificus throughout the study. Regarding the relative abundance, $18 \%$ species were very common, $30 \%$ common, $16 \%$ fairly common and $36 \%$ few. Calculating the ShannonWiener and Simpson's indices of diversity and species evenness, we found maximum number of species and individuals in the month of December while minimum in the month of July. Anthropogenic activities such as festivals, random assemblies and gatherings, dumping of plastics, polythene and papers, noise from the vehicles were common inside and around the park, which may be threats to birds.
\end{abstract}

Key words: Birds, Bangladesh, Dhaka, Ramna Park

\section{INTRODUCTION}

Bangladesh has been endowed with a rich plant and animal diversity because of its fertile alluvial land and moderate climatic condition. The climate of Bangladesh is the subtropical monsoon climate; its natural forests are classified on the basis of three major vegetation composition: evergreen to semievergreen hill forests, deciduous Sal forests and mangrove forests (Mukul 2008). Depending upon such habitat composition, Bangladesh offers shelter to a total of 690 bird species of which 380 are residents, 209 winter visitors, 11 summer visitors and 90 vagrants (Khan 2008). The total number of bird species in Bangladesh is nearly the same as all of Europe (Khan 2008). It has been

* Corresponding author: raziadubd@gmail.com

(C) 2015 Zoological Society of Bangladesh DOI: 10.3329/bjz.v43i2.27399 
reported that a great diversity of avifauna is found in the Indian subcontinent (Ali 1972, Ali and Ripley 1989).

Avifaunal diversity plays a vital role to figure out the quality and condition of environment (Bilgrami 1995). In ecological monitoring and assessments they are frequently used as indicator variables as they constitute a well defined taxon (Lin et al. 2008). Some important activities like pest control (Jaman et al. 1999), pollination, seed dispersal and sound environment are performed by birds. The values of avifauna are immense for nature as well as for human being (Jaman et al. 1999). But now-a-days, this avifaunal diversity is threatened due to anthropogenic activities. Habitat loss is the most commonly cited human threat to birds (Norris and Pain 2002). Pollution, indiscriminate cutting down of trees, climate change, unplanned infrastructure are the main causes to confine the foraging, feeding and resting sites of birds. Thus, birds are compelled to change their habitats either from urban to rural or vice-versa. Comprehensive studies are therefore, needed to protect them from their critical positions.

Ramna Park is a large park that lies in the heart of Dhaka metropolis as a green oasis in the concrete jungle featuring a beautiful and modern venue for relaxation as well as a rich place for birds. Last study on avian diversity of Ramna Park was dated back to 39 years ago (Das 1975). The present work is not only focused on bird's list but also to find out their diversity as well as their status. In addition, the study also aims at providing updated information and compilation of information on birds of the study area.

\section{MATERIAL AND METHODS}

Study area: The study was carried out in the Ramna Park $\left(23^{\circ} 44^{\prime} 14.70^{\prime \prime}\right.$ N, $90^{\circ} 24^{\prime} 03.4^{\prime \prime}$ E) which is situated in central Dhaka, Bangladesh (Fig.1). Maximum temperature was recorded $36.2^{\circ} \mathrm{C}$ in April and May and minimum $15.1^{\circ} \mathrm{C}$ in December. Ramna Park now protects an area of 68.50 acres. There is a water tank, a lake, restaurant and an office in the park of which the lake covers 8.76 acres $\left(35,500 \mathrm{~m}^{2}\right)$. The study area is mainly plain land with a moderate number of flora and fauna. The Park grows 71 species of flowering trees shrubs, perennials, and annuals, 36 species of fruit bearing plant, 33 species medicinal plant and 41 species of forestry and 11 other species Walkways inside park have been widened and five new gates built for entry from different sides. The Park features many beautiful and modern venues for relaxation which is maintained by the Public Works Department (Murshed 2012).

Observations and sampling protocol: The study was conducted from July 2013 to March 2014. Data were collected through direct field observations. Assessment of the environmental condition was conducted before collecting data. The study used to start early in the morning and continued till sunset when animals were most active. Observations were made equally across the months. Six days were spent per month in the field to observe the wild birds. Line sampling method was conducted regarding the observations of different 
species of birds. In total, 15 line samples were made and recorded at least for three times of observations. Size of the line samples varied from $500 \mathrm{~m}$ to $700 \mathrm{~m}$ in length and $30 \mathrm{~m}$ in both sides. When any species was observed, population was counted along with habitat type and food habit.

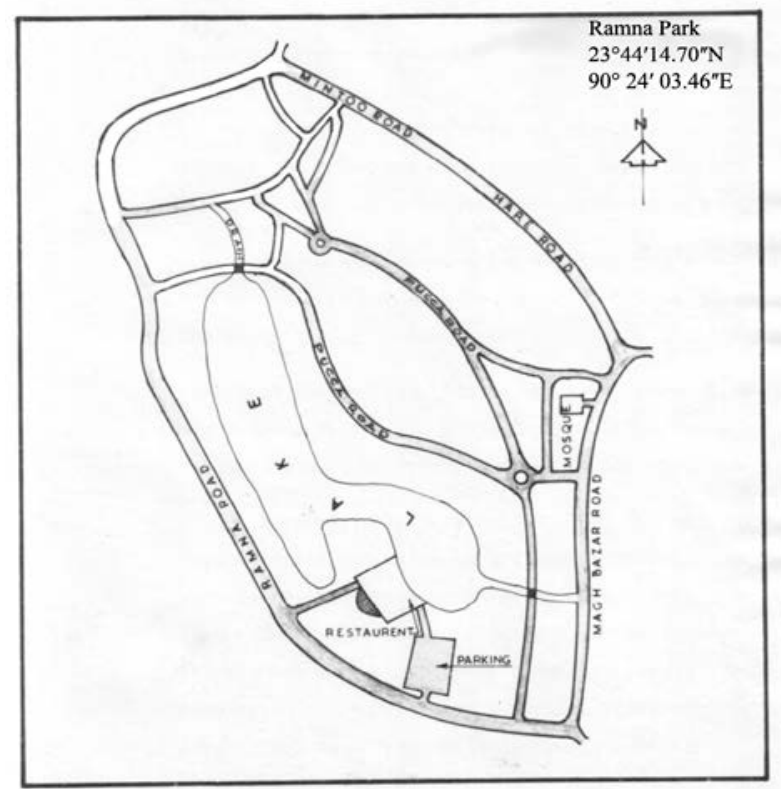

Fig. 1. Study area (Source: Dhaka South City Corporation).

Color, size and shape were the parameters that had been used to identify different species. Songs and calls had also been applied as identification criterion. During the study a pair of binoculars (Bushnell Powerview 10x42) was used. For identification of birds, Grimmett et al. (1999) and Halder (2010) were followed. In many cases, birds were photographed by D80 SLR camera in order to confirm the identification. Only the species with confirmed identification were listed. Khan (1982) was followed to estimate the relative abundance as very common (VC) 80-100\%, common (C) 50 - 79\%, fairly common (FC) $20-49 \%$ and few $(\mathrm{F}) 10-19 \%$ which was calculated based on total sighting.

Shannon-Wiener Index (1949), Simpson's index (1949) of diversity and evenness (quantifies how numerically equal the community is) of species in the study area were also calculated using following formulas:

Simpson's index of diversity, $D=1-\operatorname{sum}\left(P_{i}{ }^{2}\right)$

Shannon-Wiener Index, $H^{\prime}=-\operatorname{sum}\left(P_{i} \ln \left[P_{i}\right]\right)$ (natural log)

Evenness, $E=H^{\prime} / \ln (S)$ (natural log)

(Where, $P_{i}=$ number of individuals of a species / total number of individuals of all species from a month and $S=$ number of species observed). 
Data analysis: Data were organized and tabulated in excel spreadsheet. The analysis of data were carried out using Microsoft excel. Shannon-Wiener Index, Simpson's index of diversity and evenness were calculated according to the month.

\section{RESULT AND DISCUSSION}

Faunal composition of avifauna: A total of 50 species of birds were found belonging to 11 orders and 28 families. Passeriformes had the maximum number ( 25 species) of birds followed by Piciformes ( 4 species), Coraciformes ( 3 species), Strigiformes ( 3 species), Pelecaniformes ( 2 species), Columbiformes (2 species), Cuculiformes ( 3 species), Psittaciformes (2 species), Apodiformes (3 species), Acciptriformes (2 species) and Suliformes (1 species) (Table 1). Das (1975) recorded 37 species of birds in Ramna Park. Sarker et al. (2007) observed a total of 27 species of birds from two different sites in Dhaka, Bangladesh. A total of 50 species of avifauna were found from the Curzon hall premises, Dhaka University (Akash et al. 2013). Chowdhury et al. (2014) recorded 78 species of birds from the Dhaka university campus. The present study observed 50 species of birds that depict, the study area could be a better home to birds as it supports many flowering plants, fruiting trees, shrubs, large trees and lake inside the park.

Status and relative abundance of avifauna: Overall relative abundance showed that $18 \%$ birds were very common, $30 \%$ common, $16 \%$ fairly common and $36 \%$ few. (Fig. 2). Highest number of individuals were found in the month of December (534 individuals) followed by January (481 individuals) and February (409 individuals) and lowest numbers were in the month of July (189 individuals) followed by August (305 individuals) and September (350 individuals) (Fig. 3). Corvus splendens was the dominating species followed by Passer domesticus and Acridotheres tristis among the observed avifauna in the Ramna Park. Only Clamator jacobinus, Psittacula eupatria and Apus pacificus were observed in the month of September, August and January respectively. Corvus splendens is the scavenger bird which mainly feeds on waste products. So the highest population of this species indicates that the environment of Ramna Park is not clean in comparison to the other parts of Dhaka. We observed insectivorous birds such as Dicrurus macrocercus which acts as pest controlling agent especially insect pests. Jaman et al. (1999) studied that birds are considered as friends of human as they demolish a lot of harmful insects and mosquitoes from the environment. 


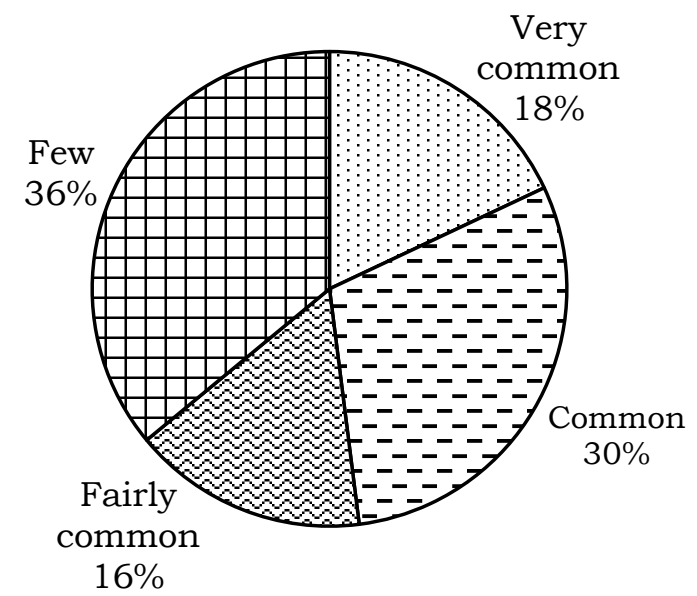

Fig. 2. Relative abundance of recorded avifauna in the study area.

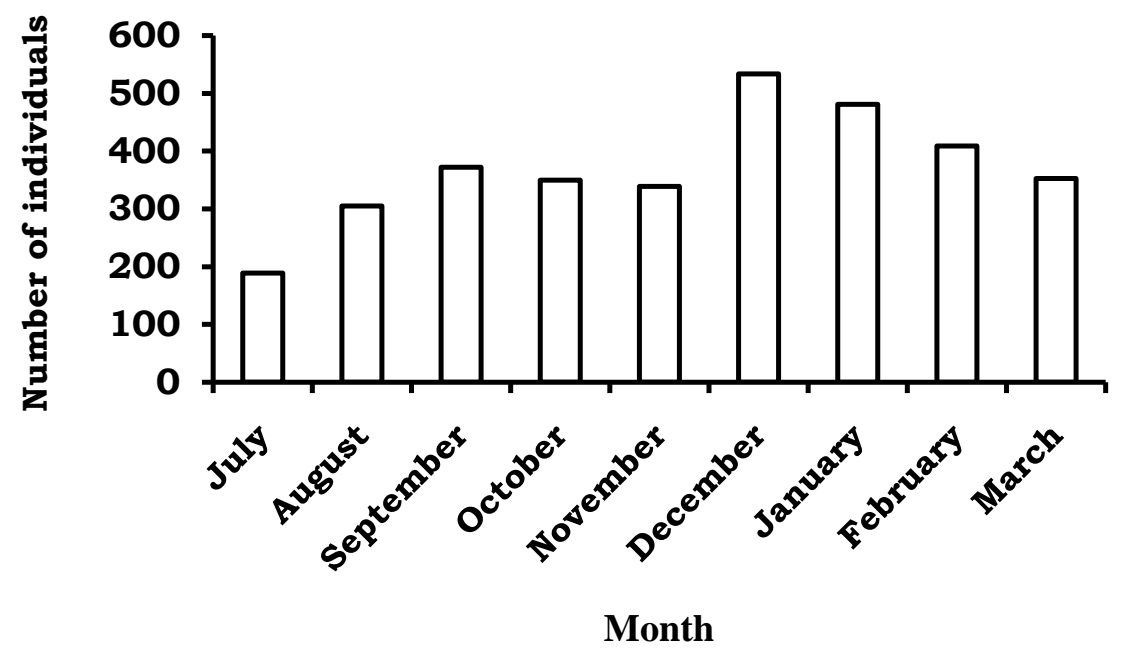

Fig. 3. Monthly variation of observed individuals of birds in the study area.

Resident and migrant status of birds: Among 50 species of birds, 84\% were identified as residents and $16 \%$ migrants including winter migrant and summer migrant, 50\% passerines and 50\% non-passerines (Table 1). Among migratory birds, only Clamator jacobinus was the summer migrant. We found only one species (Psittacula eupatria) which is considered as globally Near Threatened (NT) birds. The resident and migrant status of this suggests that the study area still has a place for roosting, feeding, foraging and breeding sites for birds.

Species diversity indices: The value of Shannon-Weiner index was calculated to be highest $\left(H^{\prime}=3.209\right)$ in the month of December and lowest $\left(H^{\prime}=2.899\right)$ in the 
month of July. Similarly, value of Simpson's index of diversity was found to be maximum $(D=0.947)$ in the month of December and minimum $(D=0.921)$ in the month of July (Table 2). These calculated values indicate that the species diversity was greater (43 species) in December in comparison to July (28 species). We also calculated species evenness where birds species were more evenly distributed $(E=0.820)$ in the month of December and less distributed $(E=0.741)$ in the month of July (Table 2). December is winter month of when migratory birds visited inside the park and constituted the highest species diversity along with resident birds. In contrast, for being warmer in the month of July there was no migratory birds that results low species diversity. In addition, July was the first month of data collection that might be another reason for the lowest diversity of species. For the avian fauna of Tilyar lake, Rohtak (Haryana, India), Singh and Laura (2013) reported the highest values of diversity indices in the month of December and lowest in the month of July. Another study found that high species diversity in December may be presence of migratory birds for food, proper foraging and breeding sites (Maheswaran and Rahmani 2001, Albores and Siguenza 2011). On the other hand, high temperature, low food availability and local migration of migratory avian fauna to nearby agriculture fields for food may be the reason for low species diversity in the month of July (Maheswaran and Rahmani 2001). Present findings match with those studies.

Problems and threats: We observed some problems and threats inside the Park area. Problems and threats include dumping of wastes materials such as plastics, polythene, chips packets as well as other unused papers. Anthropogenic movements, gatherings, festivals, selling of foods by hawkers, restaurant inside the Park and noise from the outside vehicles were considered as problems. Furthermore, people extensively used and still using this park area as short-cuts for communication to their destinations. These problems and threats might be affecting the bird species in the study area. (Hossain et al. 2004) reported that wild animals are losing their habitat due to anthropogenic activities in Hatiya Island, Bangladesh. Chopra and Rani (2015) also studied that anthropogenic activities causes major threats to avifauna in Chilli Lake, Fatehabad, Haryana, India. 
Table 1. List of Avifauna in Ramna Park, Dhaka from July 2013- March 2014.

\begin{tabular}{|c|c|c|c|c|c|c|c|c|}
\hline Order & Family Name & Scientific Name & English Name & $\begin{array}{l}\text { Individuals } \\
\text { observed }\end{array}$ & $\begin{array}{c}\text { Popn }^{\mathbf{n}} \\
\text { status, } \\
\text { (Local }^{*} \text { ) }\end{array}$ & $\begin{array}{c}\text { CS } \\
\text { (Global*) }\end{array}$ & $\mathbf{R} / \mathbf{M}$ & Group \\
\hline \multirow{26}{*}{ Passeriformes } & \multirow{4}{*}{ Sturnidae } & Sturnus contra & Asian Pied Starling & 202 & $\mathrm{VC}$ & LC & $\mathrm{R}$ & $\mathrm{Pa}$ \\
\hline & & Acridotheres tristis & Common Myna & 306 & $\mathrm{VC}$ & $\mathrm{LC}$ & $\mathrm{R}$ & $\mathrm{Pa}$ \\
\hline & & Acridotheres fuscus & Jungle Myna & 214 & $\mathrm{VC}$ & $\mathrm{LC}$ & $\mathrm{R}$ & $\mathrm{Pa}$ \\
\hline & & Sturnus malabaricus & Chestnut-tailed Starling & 73 & $\mathrm{VC}$ & $\mathrm{LC}$ & $\mathrm{R}$ & $\mathrm{Pa}$ \\
\hline & Pycnonotidae & Pycnonotus cafer & Red-vented Bulbul & 273 & $\mathrm{VC}$ & $\mathrm{LC}$ & $\mathrm{R}$ & $\mathrm{Pa}$ \\
\hline & Cisticolidae & Orthotomus sutorius & Common Tailorbird & 104 & $\mathrm{C}$ & LC & $\mathrm{R}$ & $\mathrm{Pa}$ \\
\hline & Acrocephalidae & Acrocephalus stentoreus & Clamorous Reed Warbler & 5 & $\mathrm{~F}$ & LC & $\mathrm{M}_{\mathrm{w}}$ & $\mathrm{Pa}$ \\
\hline & \multirow{2}{*}{ Nectarinidae } & Nectarinia zeylonica & Purple-rumped Sunbird & 26 & $\mathrm{FC}$ & $\mathrm{LC}$ & $\mathrm{R}$ & $\mathrm{Pa}$ \\
\hline & & Nectarinia asiaticus & Purple Sunbird & 26 & $\mathrm{FC}$ & LC & $\mathrm{R}$ & $\mathrm{Pa}$ \\
\hline & Decaidae & Dicaeum erythrorhynchos & Pale-billed Flowerpecker & 4 & $\mathrm{~F}$ & $\mathrm{LC}$ & $\mathrm{R}$ & $\mathrm{Pa}$ \\
\hline & Passeridae & Passer domesticus & House Sparrow & 350 & $\mathrm{VC}$ & $\mathrm{LC}$ & $\mathrm{R}$ & $\mathrm{Pa}$ \\
\hline & \multirow{2}{*}{ Laniidae } & Lanius schach & Long-tail Shrike & 17 & $\mathrm{FC}$ & $\mathrm{LC}$ & $\mathrm{R}$ & $\mathrm{Pa}$ \\
\hline & & Lanius cristatus & Brown Shrike & 5 & $\mathrm{~F}$ & $\mathrm{LC}$ & $\mathrm{M}_{\mathrm{w}}$ & $\mathrm{Pa}$ \\
\hline & Motacillidae & Motacilla alba & White Wagtail & 34 & $\mathrm{C}$ & $\mathrm{LC}$ & $\mathrm{M}_{\mathrm{w}}$ & $\mathrm{Pa}$ \\
\hline & Estrilidae & Lonchura punctulata & Scaly-breasted Munia & 6 & $\mathrm{~F}$ & LC & $\mathrm{R}$ & $\mathrm{Pa}$ \\
\hline & Paridae & Parus major & Great Tit & 21 & $\mathrm{FC}$ & LC & $\mathrm{R}$ & $\mathrm{Pa}$ \\
\hline & \multirow{4}{*}{ Corvidae } & Oriolus xanthornus & Black-hooded Oriole & 50 & $\mathrm{C}$ & $\mathrm{LC}$ & $\mathrm{R}$ & $\mathrm{Pa}$ \\
\hline & & Dendrocitta vagabunda & Rofous Treepie & 48 & $\mathrm{C}$ & $\mathrm{LC}$ & $\mathrm{R}$ & $\mathrm{Pa}$ \\
\hline & & Corvus macrorhynchus & Large-billed Crow & 67 & $\mathrm{C}$ & $\mathrm{LC}$ & $\mathrm{R}$ & $\mathrm{Pa}$ \\
\hline & & Corvus splendens & House Crow & 388 & $\mathrm{VC}$ & $\mathrm{LC}$ & $\mathrm{R}$ & $\mathrm{Pa}$ \\
\hline & \multirow[t]{2}{*}{ Dicruridae } & Dicrurus macrocercus & Black Drongo & 163 & $\mathrm{VC}$ & $\mathrm{LC}$ & $\mathrm{R}$ & $\mathrm{Pa}$ \\
\hline & & Dicrurus leucophaeus & Ashy Drongo & 6 & $\mathrm{~F}$ & $\mathrm{LC}$ & $\mathrm{M}_{\mathrm{w}}$ & $\mathrm{Pa}$ \\
\hline & \multirow[t]{2}{*}{ Muscicapidae } & Copsychus saularis & Oriental Magpie Robin & 204 & $\mathrm{VC}$ & $\mathrm{LC}$ & $\mathrm{R}$ & $\mathrm{Pa}$ \\
\hline & & Ficedulla albicilla & Taiga Flycatcher & 6 & $\mathrm{C}$ & $\mathrm{LC}$ & $\mathrm{M}_{\mathrm{w}}$ & $\mathrm{Pa}$ \\
\hline & Turdoidae & Zoothera citrine & Orange-headed Thrush & 7 & $\mathrm{~F}$ & LC & $\mathrm{R}$ & $\mathrm{Pa}$ \\
\hline & Megalaimidae & Megalaima haemacephala & Coppersmith Barbet & 9 & $\mathrm{~F}$ & LC & $\mathrm{R}$ & NP \\
\hline Piciformes & Picidae & Dinopium benghalense & Black-rumped Flameback & 64 & $\mathrm{C}$ & LC & $\mathrm{R}$ & NP \\
\hline
\end{tabular}




\begin{tabular}{|c|c|c|c|c|c|c|c|c|}
\hline Order & Family Name & Scientific Name & English Name & $\begin{array}{l}\text { Individuals } \\
\text { observed }\end{array}$ & $\begin{array}{c}\text { Popn } \\
\text { status, } \\
\text { (Local*) }\end{array}$ & $\begin{array}{c}\text { CS } \\
\text { (Global*) }\end{array}$ & $\mathbf{R} / \mathbf{M}$ & Group \\
\hline \multirow{5}{*}{ Coraciiformes } & & Dendrocopos macei & $\begin{array}{l}\text { Fulvous-breasted } \\
\text { Woodpecker }\end{array}$ & 7 & $\mathrm{~F}$ & $\mathrm{LC}$ & $\mathrm{R}$ & NP \\
\hline & & Celeus brachyurus & Rufous Woodpecker & 2 & $\mathrm{~F}$ & LC & $\mathrm{R}$ & NP \\
\hline & Alcedinidae & Alcedo atthis & Common Kingfisher & 43 & $\mathrm{C}$ & $\mathrm{LC}$ & $\mathrm{R}$ & NP \\
\hline & Halcyonidae & Halcyon smyrnensis & White-throated Kingfisher & 18 & $\mathrm{FC}$ & $\mathrm{LC}$ & $\mathrm{R}$ & NP \\
\hline & Meropidae & Merops orientalis & Green Bee-eater & 27 & $\mathrm{FC}$ & $\mathrm{LC}$ & $\mathrm{M}_{\mathrm{w}}$ & NP \\
\hline \multirow{3}{*}{ Strigiformes } & & Athene brama & Spotted Owlet & 47 & $\mathrm{C}$ & $\mathrm{LC}$ & $\mathrm{R}$ & NP \\
\hline & Strigidae & Tyto alba & Barn Owl & 10 & $\mathrm{~F}$ & $\mathrm{LC}$ & $\mathrm{R}$ & NP \\
\hline & & Ninox scutulata & Brown Hawk Owl & 2 & $\mathrm{~F}$ & $\mathrm{LC}$ & $\mathrm{R}$ & NP \\
\hline \multirow{2}{*}{ Pelecaniformes } & Ardeidae & Egretta garzetta & Little Egret & 4 & $\mathrm{~F}$ & $\mathrm{LC}$ & $\mathrm{R}$ & NP \\
\hline & & Ardeola grayii & Indian Pond Heron & 26 & $\mathrm{FC}$ & $\mathrm{LC}$ & $\mathrm{R}$ & NP \\
\hline \multirow{3}{*}{ Columbiformes } & Columbidae & Columba livia & Common Pigeon & 54 & $\mathrm{C}$ & $\mathrm{LC}$ & $\mathrm{R}$ & NP \\
\hline & & Streptopelia chinensis & Spotted Dove & 43 & $\mathrm{C}$ & $\mathrm{LC}$ & $\mathrm{R}$ & NP \\
\hline & & Hierococcyx varius & Common Hawk Cuckoo & 10 & $\mathrm{~F}$ & LC & $\mathrm{R}$ & NP \\
\hline \multirow[t]{2}{*}{ Cuculiformes } & Cuculidae & Clamator jacobinus & Pied Cuckoo & 1 & $\mathrm{~F}$ & $\mathrm{LC}$ & $\mathrm{M}_{\mathrm{s}}$ & NP \\
\hline & & Eudynamys scolopaceus & Asian Koel & 22 & $\mathrm{FC}$ & $\mathrm{LC}$ & $\mathrm{R}$ & NP \\
\hline \multirow{3}{*}{ Psittaciformes } & Psittacidae & Psittacula krameri & Rose-ringed Parakeet & 105 & $\mathrm{C}$ & LC & $\mathrm{R}$ & NP \\
\hline & & Psittacula eupatria & Alexandrine Parakeet & 1 & $\mathrm{~F}$ & NT & $\mathrm{R}$ & NP \\
\hline & & Cypsiurus balasiensis & Asian Palm Swift & 49 & $\mathrm{C}$ & $\mathrm{LC}$ & $\mathrm{R}$ & NP \\
\hline \multirow[t]{2}{*}{ Apodiformes } & Apodidae & Apus affinis & House Swift & 69 & $\mathrm{C}$ & $\mathrm{LC}$ & $\mathrm{R}$ & NP \\
\hline & & Apus pacificus & Forked tail swift & 1 & $\mathrm{~F}$ & $\mathrm{LC}$ & $\mathrm{M}_{\mathrm{w}}$ & NP \\
\hline \multirow[t]{2}{*}{ Acciptriformes } & Accinitridae & Milvus migrans & Black Kite & 95 & $\mathrm{C}$ & $\mathrm{LC}$ & $\mathrm{R}$ & NP \\
\hline & Accipitridae & Haliastur indus & Brahminy Kite & 9 & $\mathrm{~F}$ & $\mathrm{LC}$ & $\mathrm{R}$ & NP \\
\hline Suliformes & Phalacrocoracidae & Phalacrocorax niger & Little Cormorant & 7 & $\mathrm{~F}$ & LC & $\mathrm{R}$ & NP \\
\hline
\end{tabular}

Note: VC-Very common, C-Common, FC-Fairly Common, F-Few, LC-Least Concern, Pop ${ }^{\mathrm{n}}-$ Population, R/M- Resident and migrant status, R-Resident, M-Migrant, $\mathrm{M}_{\mathrm{s}}$ - Summer migrant, $\mathrm{M}_{\mathrm{w}}$ - winter migrant, Pa- Passerine, NP- Non-Passerine, CS- Conservation status, Local ${ }^{*}$-Study site and Global*-Version 2015-3. www.iucnredlist.org 
Table 2. Species diversity indices according to month.

\begin{tabular}{|c|c|c|c|c|c|c|c|c|c|}
\hline Parameter & July & Aug & Sep & Oct & Nov & Dec & Jan & Feb & Mar \\
\hline $\begin{array}{l}\text { Shannon-Wiener } \\
\text { index }\left(H^{\prime}\right)\end{array}$ & 2.899 & 2.996 & 3.039 & 3.020 & 3.047 & 3.209 & 3.069 & 3.077 & 2.925 \\
\hline $\begin{array}{l}\text { Simpson's index of } \\
\text { diversity }(D)\end{array}$ & 0.921 & 0.930 & 0.934 & 0.935 & 0.933 & 0.947 & 0.935 & 0.934 & 0.931 \\
\hline Evenness $(E)$ & 0.741 & 0.766 & 0.777 & 0.772 & 0.779 & 0.820 & 0.784 & 0.787 & 0.750 \\
\hline Species observed & 28 & 34 & 36 & 35 & 40 & 43 & 40 & 42 & 34 \\
\hline Individual observed & 189 & 305 & 372 & 350 & 339 & 534 & 481 & 409 & 353 \\
\hline
\end{tabular}

Note: Aug-August. Sep-September, Oct-October, Nov-November, Dec-December, Jan-January, Feb-February and Mar-March 
In conclusion, we observed 50 species of birds belonging to 11 order and 28 families. This figure indicates that the Ramna Park is the potential habitat for the birds. However, some anthropogenic threats had been observed that might be affecting the birds in the study area. So, elaborate study is needed in that area. Massive steps including conservation measures with awareness and punishment must be taken to bring sound environment inside the park.

Acknowledgements: At first we express unending gratefulness to the Almighty Allah for blessing us in all aspects of life. We wish to express our gratitude to Dr. MA Howlader, former Chairman and Professor, Department of Zoology, University of Dhaka for his kind permission and for providing facilities to conduct this research.

\section{LITERATURE CITED}

AKASH, M., HOSSAIN, M. A., CHOWDHURY, G. W., MAHMUD, H. and ISLAM, M. A. 2013. Status of avifauna in Curzon Hall premises University of Dhaka, Bangladesh. Ecoprint. 20: 1-8.

ALBORES, J. E. R. and SIGÜENZA, A. G. N. 2011. Relationships between bird species richness and natural and modified habitat in Southern Mexico. In: Changing Diversity in Changing Environment. (Ed., Grillo, O.). 932 pp. http://www.intechopen.com/books/changing-diversity-in-changing

ALI, S. 1972. The book of Indian Birds. 9th ed. Bombay Natural Historical Society, Bombay. India.

ALI, S. and RIPLEY, S. D. 1989. Compact Handbook of the Birds of India and Pakistan Together With Those of Bangladesh, Nepal, Bhutan and Sri Lanka. 2nd ed. Oxford University Press, Delhi, India. $882 \mathrm{pp}$.

BILGRAMI, K.S. 1995. Concept and Conservation of Biodiversity. CBS Publishers and Distributors, New Delhi.

CHOPRA, G. and RANI, P. 2015. Species Diversity and Abundance of Birds of Chilli Lake, Fatehabad, Haryana. Int. J. Inn. Res.Dev. 5(4):156-162.

CHOWDHURY, S., AICH, U. and SHAHADAT, O. 2014. Checklist of avian fauna of Dhaka University Campus, Bangladesh. Int. J. Fauna. Biol. Stud. 1 (5): 56-60.

DAS, A.K. 1975. A study on birds of Curzon Hall and Ramna Park. M.S. thesis (unpubl.), Dept. of Zoology, University of Dhaka.

GRIMMETT, R., INSKIPP, C. AND INSKIPP, T. 1999. Pocket Guide to the Birds of the Indian Subcontinent. Oxford University Press, New Delhi.384 pp.

HALDER, R.R. 2010. A Photographic Guide to Birds of Bangladesh. Baikal Teal Publication, Dhaka, Bangladesh. 257 pp.

HOSSAIN, M.K., JAMAN, M.F. and SARKER, S.U. 2004. Diversity of herpeto-mammalian fauna and their conservation issues in Hatiya island, Bangladesh. Tropi. Biod. 8(2):71-78.

IUCN Red List of Threatened Species. Version 2015-3. (www.iucnredlist.org). 
JAMAN, M.F., SARKER, S.U. and SARKER, N.J. 1999. Food habits and feeding behavior of black drongo, Dicrurus macrocercus albirictus (Hodgson). Bangladesh J. Zool. 26(2):57 66.

KHAN, M. A. R. 1982. Wildlife of Bangladesh (A checklist). University of Dhaka. Dhaka. $173 \mathrm{pp}$.

KHAN, M.M.H. 2008. Protected Areas of Bangladesh- A. Guide to Wildlife. Nishorgo Support Program, Bangladesh. Forest Department. 304 pp.

LIN, Y. P., YEH, M. S., DENG, D. P. and WANG, Y. C. 2008. Geostatistical approaches and optimal additional sampling schemes for spatial patterns and future sampling of bird diversity. Global Ecol. Biogeogr. 17(2): 175-188.

MAHESWARAN, G. and RAHMANI, A.R. 2001. Effects of water level changes and wading bird abundance on the foraging behavior of black-necked stork, Ephippiorhynchus asiaticus in Dudwa National Park, India. J. Biosci. 26: 373-382.

MANJU, A.H. 2001. Tk. 382 crore projects for conservation of biodiversity in the Sundarbans. In: State of Sundarbans. Forum of Environmental Journalists of Bangladesh (FEJB). (ed., Chowdhury, Q.I.). Dhaka. pp.89-91.

MUKUL, S.A. 2008. Biodiversity Conservation Strategies in Bangladesh: The State of Protected Areas. Tiger Paper 34(4): 28-32.

MURSHED, S.M. 2012. In: Banglapedia: National Encyclopedia of Bangladesh (Ed., Islam, S. and Jamal, A.A.) Asiatic Society of Bangladesh. 4810 pp.

NORRIS, K. and PAIN, D. 2002. Conserving Bird Biodiversity: General Principles and their Application. Cambridge University Press.

SARKAR, N.J., Sultana, D., Jaman, M. F. and Rahman, M. K. 2009. Diversity and population of avifauna of two urban sites in Dhaka, Bangladesh. Ecoprint 16: 1-7.

SHANNON, C.E. and WIENER, W. 1949. The mathematical theory. University of Illinois Press, Urbana. 117 pp.

SIMPSON, E. H. 1949. Measurement of diversity. Nature. 163: 688.

SINGH, A. and LAURA, J.S. 2013. Avifauna Species Diversity and their Abundance in Tilyar Lake, Rohtak, Haryana (India). Bulletin of Environment. Pharmacol. Life Sci. 3 (1): 180-185.

(Manuscript received on 4 June, 2015; revised on 30 December, 2015) 